\title{
Use of life quality indicators in assessing the effectiveness of agriculture state regulation instruments
}

\author{
Irina Maksimova \\ Volgograd Institute of management - the branch of Ranepa \\ Economic faculty \\ Volgograd, Russia \\ maksimova_irina_2017@mail.ru
}

\author{
Tamara Polikarpova \\ Volgograd Institute of management - the branch of \\ Ranepa Economic faculty \\ Volgograd, Russia \\ polikarpovati@mail.ru
}

\author{
Ekaterina Rodionova \\ Volgograd Institute of management \\ the branch of Ranepa Economic faculty \\ Volgograd, Russia \\ rodionovaka@yandex.ru
}

\begin{abstract}
The article examines the problem of agriculture economic regulation instruments effectiveness assessment improving. With the help of empirical material, the authors study the shortcomings of existing approaches in assessing the federal and regional target programs effectiveness. In order to improve programs effectiveness assessment the authors propose to use the population life quality indicators more widely.
\end{abstract}

Keywords - life quality indicators, state regulation effectiveness assessment, effectiveness assessment, federal and regional targeted programs effectiveness assessment

\section{INTRODUCTION}

Agricultural industry should now be considered as a priority sector of domestic production. The annual import of food products to Russia amounts to tens of billions of US dollars. It means high food dependence and economic perils for Russia. An even greater problem arising in this connection is the population life quality growth containment. The reason for this is possible shortage of food supply from abroad and not always fresh perishable products. They can reduce the quality of meeting population basic needs significantly including needs in food.

Special categories in the structure of agricultural production are meat and by-products. The consumption of these products is necessary to replenish protein in the body. These are the proteins that give the bulk of food energy, building material for cells and amino acids to maintain a normal state of blood.
To solve the problem of the domestic agricultural production growth, the state spends billions of rubles annually within the framework of the implementation of federal and regional target programs. However, changes in the volume of agricultural production indicators are mainly used in assessing programs efficiency [1]. In this regard, studies aimed at improving the methods for assessing the federal and regional target programs effectiveness, primarily through the use of indicators characterizing the population life quality, acquire particular relevance. On the example of programs for the development of livestock and poultry industries the case is about indicators that characterize the consumer satisfaction of the population in meat and meat products.

The purpose of this study is a rationale for the use of life quality indicators in assessing federal and regional target programs for the development of livestock and poultry industries, namely, the satisfaction indices of the population of Russia in meat and meat products.

\section{MATERIALS AND METHODS (MODEL)}

To conduct the study we used the data of Russian Federal State Statistics Service for 2010-2017. For the overall assessment of meeting the needs of the population the methods of comparative analysis of the volume of meat and meat products consumption in general across the Russian Federation and in the context of specific regions in dynamics for a number of years were used. 
In order to assess the degree of meeting the needs of the population for homegrown meat and meat products, volume ratio indicator of homegrown meat and by-products to the total consumption of meat and meat products in the Russian Federation was used.

To assess the effectiveness of state regulation of domestic production of meat and by-products, growth (decrease) indices of meat and by-products production volume per capita and growth (decrease) indices of meat and meat products consumption per capita were analyzed.

\section{RESULTS AND DISCUSSION}

The current state of consumer satisfaction degree in meat and meat products in the Russian Federation is clearly shown in Fig. 1. It can be seen from the figure that meat and meat products consumption in Russia is much lower than in economically developed countries. According to statistics, on average, one Russian consumes meat and meat products 1.3 times less than in Germany and France, 1.2 times less than in the UK, 1.7 times less than in the US [2].

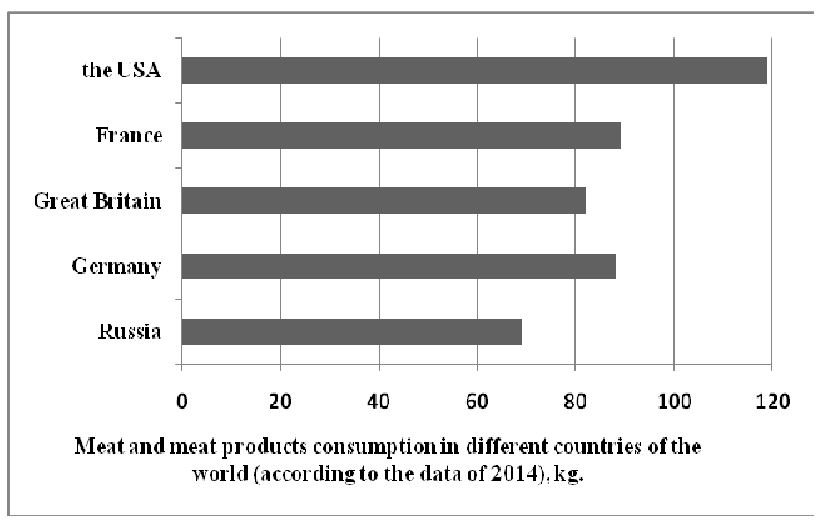

Fig. 1. Meat and meat products consumption in different countries of the world (according to the data of 2014), $\mathrm{kg}$.

At the same time, the average per capita meat and meat products consumption in the regions of Russia is highly heterogeneous. Thus, for example, according to the data of 2016, the volume of meat consumption in the average for the Russian Federation was $74 \mathrm{~kg}$, in the regions of the Urals Federal District - $69 \mathrm{~kg}$., and in the regions of the Central Federal District - $81 \mathrm{~kg}$. [3].

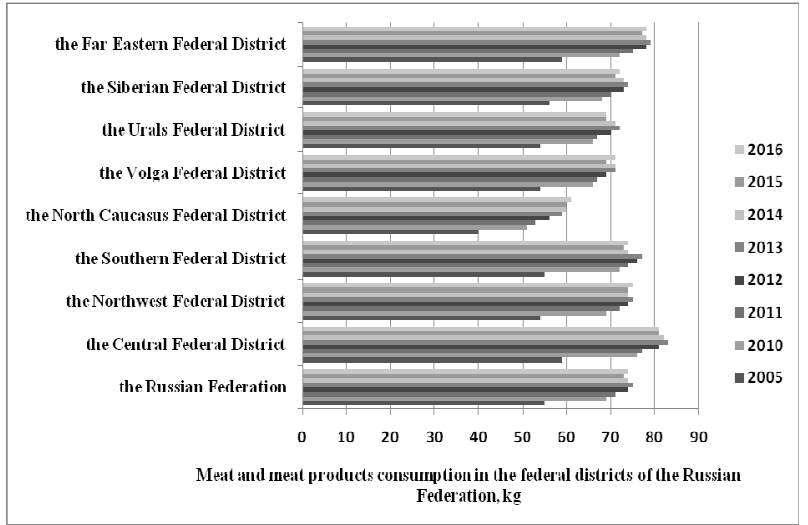

Fig. 2. Meat and meat products consumption in the federal districts of the Russian Federation, $\mathrm{kg}$.

The anti-crisis measures of the Government of the Russian Federation for the domestic agricultural production development together with the implementation of federal and regional target programs to support agricultural producers undoubtedly influence the state of the industry. It is indirectly indicated by statistical data on the growth of meat and byproducts manufacturing in the regions of the Russian Federation (Fig. 3) [3].

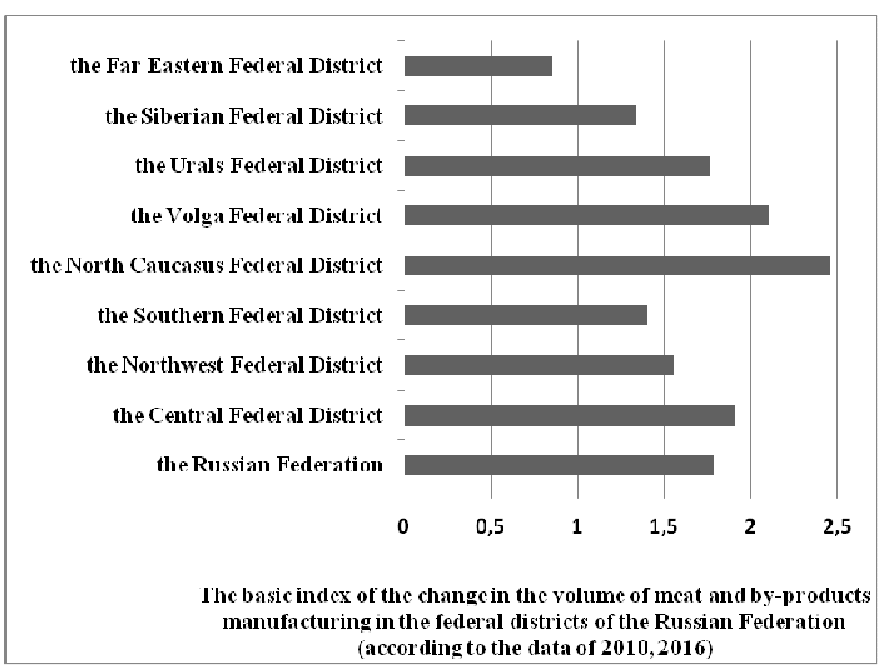

Fig. 3. The basic index of the change in the volume of meat and by-products manufacturing in the federal districts of the Russian Federation (according to the data of 2010, 2016)

According to statistics the volume of meat and by-products manufacturing increased by 18 thousand tons or 1.8 times between 2010 and 2016. At the same time the growth in meat and by-products manufacturing grew 1.9 times in the Central Federal District, 1.6 times in the Northwest Federal District, 1.4 times in the Southern Federal District, 2.5 times in the North Caucasus Federal District, 2.1 times in the Volga Federal District, 1.8 times in the Urals Federal District, 1.3 times in the Siberian Federal District. The exception is the Far Eastern Federal District where the volume of meat and byproducts manufacturing decreased by 0.85 times (Fig. 3) [3]. 
Based on these results, it is obvious that we can conclude that state regulation instruments have a positive impact on the development of the sectors under consideration. However, for a more complete assessment it is necessary to conduct more detailed studies, for example, using the index chain rate of change in output. Thus, according to the data, its average value in the federal districts did not exceed 1.1 times during the period under review (Fig. 4) [3], which may indicate low increase in production volume. It is possible to assume that such low growth rates could not significantly affect the reduction of Russia's food dependence and a noticeable improvement in the population life quality.

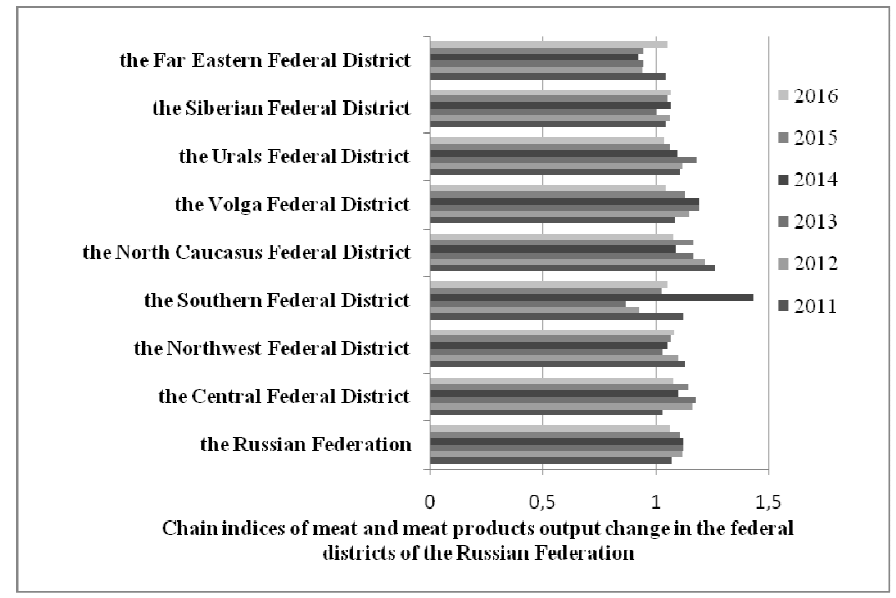

Fig. 4. Chain indices of meat and meat products output change in the federal districts of the Russian Federation

The indicators characterizing the degree of consumer satisfaction in meat and meat products were calculated for a more objective conclusion about the effectiveness of the state regulation of agricultural industries. The growth rate of consumption of meat and meat products per capita can be used among such indicators. The calculations show that the volume of consumption of meat and meat products in the federal districts of the Russian Federation in per capita terms increased significantly from 2010 to 2016 (Fig. 5) [3].

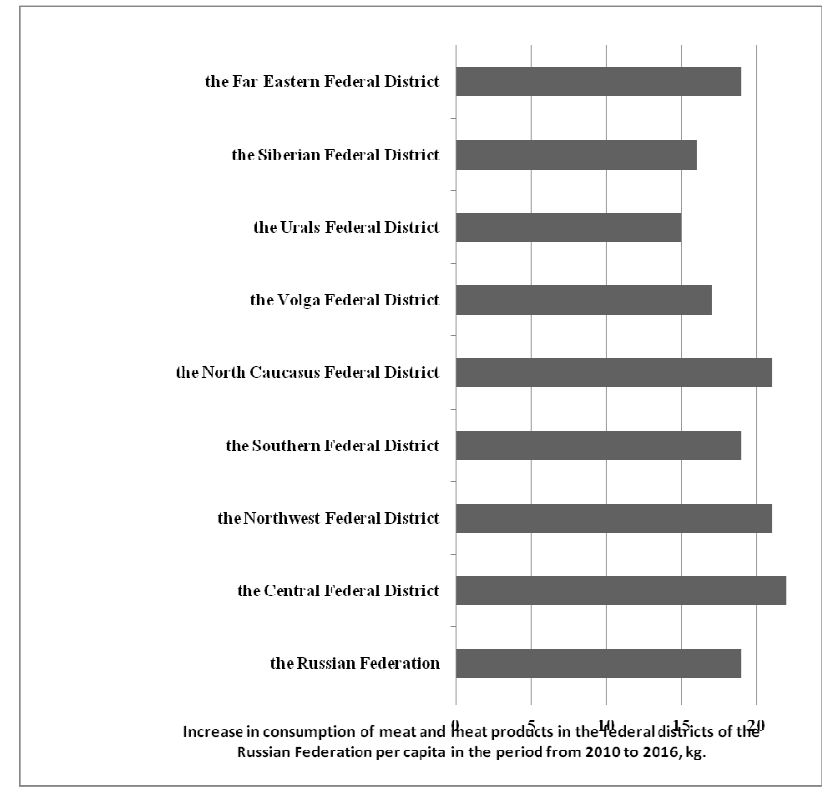

Fig. 5. Increase in consumption of meat and meat products in the federal districts of the Russian Federation per capita in the period from 2010 to $2016, \mathrm{~kg}$.

The greatest growth of this indicator (higher than the average for Russia) is observed in the Central, North-Western and North-Caucasian federal districts. The study showed that there was an increase in meat and meat products consumption per capita even in the Far Eastern Federal district where there was a decrease in meat and by-products manufacturing. This suggests that the increase in consumption is mainly due to the increase in purchases of meat and by-products from imports, rather than to the increase in domestic production.

To confirm this assumption calculations of the lead (lag) index in terms of the meat and by-products manufacturing volume per capita index and the meat and meat products consumption per capita index were made (Fig.6) [3].

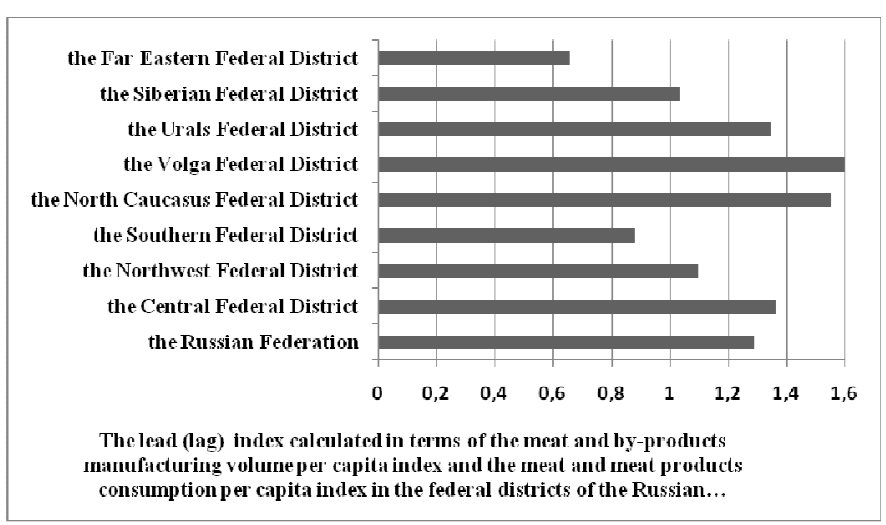

Fig. 6. The lead (lag) index calculated in terms of the meat and by-products manufacturing volume per capita index and the meat and meat products consumption per capita index in the federal districts of the Russian Federation (according to the data of 2010-2016). 
According to the data received, the lead (lag) index is higher than 1 in almost all the federal districts of the Russian Federation. The Southern and Far Eastern Federal Districts are the exception. This means that the growth rates of meat and by-products manufacturing outpaced the growth of meat and meat products consumption in the prevailing number of federal districts of the Russian Federation during the period under study.

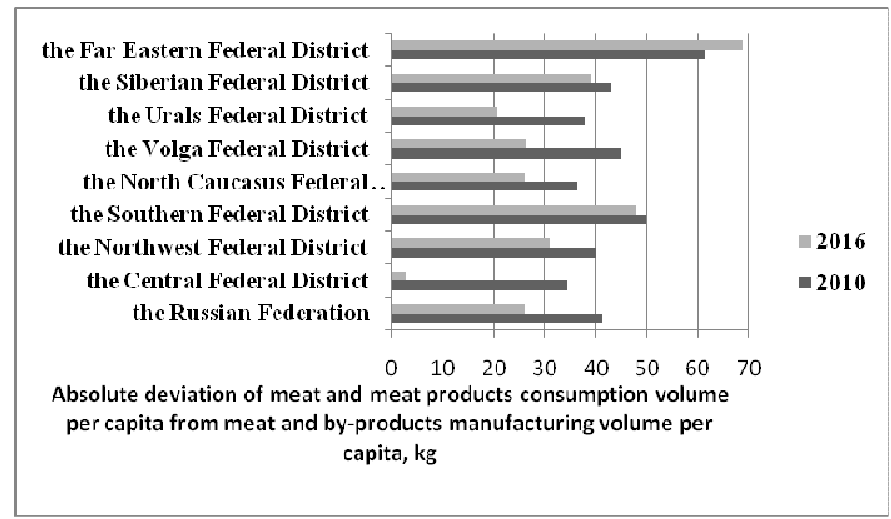

Fig. 7. Absolute deviation of meat and meat products consumption volume per capita from meat and by-products manufacturing volume per capita, $\mathrm{kg}$

Calculation of another indicator, absolute deviation of meat and meat products consumption volume per capita from meat and by-products manufacturing volume per capita (Fig.7) [3] shows that in all the federal districts the needs of the population in meat and meat products are met mainly through imports of these products.

If we take the average for Russia, the ratio of the indicator of meat and by-products domestic manufacturing per capita volume to the indicator of meat and meat products consumption volume per capita is about $64 \%$. This ratio is about $96 \%$ in the Central Federal District, about $59 \%$ in the North-West Federal District, about 35\% in the Southern Federal District, about $57 \%$ in the North Caucasus Federal District, about $62 \%$ in the Volga Federal District, about $49 \%$ in the Siberian Federal District, and about $11 \%$ in the Far Eastern Federal District.
The data of the last two calculated indicators make it possible to say that despite some increase in meat and meat products consumption in the Southern, Siberian and especially in the Far Eastern Federal Districts, the needs of the population are met mainly through imports, which can affect the quality of products and the degree of consumer satisfaction.

\section{CONCLUSION}

Summarizing the study, the following conclusions can be drawn.

The existing methods for assessing the effectiveness of federal and regional target programs need to be improved. The main drawback of the methods used to assess the effectiveness of target programs for the development of industries and complexes is in underestimating the importance of social indicators. Expediency of population life quality indicators use is shown by the example of improving the effectiveness of federal and regional target programs for the development of livestock and poultry industries assessment.

Population life quality indicators in this study are the lead (lag) index calculated in terms of the meat and by-products manufacturing volume per capita index and the meat and meat products consumption per capita index and absolute deviation of meat and meat products consumption volume per capita from meat and by-products manufacturing volume per capita. These indicators reflect the degree of the population consumer satisfaction.

\section{References}

[1] "The theory of sustainable development of economy and industry" Aletdinova A. A, Bulatova N. N, Buyanova M. E. and other. Saint-Petersburg, 2016

[2] Russia and countries of the world. [Electronic resource]: URL http://www.gks.ru

[3] Region of Russia. Socio-economic indicators. [Electronic resource]: URL http://www.gks.ru 